\title{
SIMULASI MIKRO
}

PAPER UAS

Firm Performance, Entrepreneurial Orientation, dan Pengaruh Budaya Organisasi Dalam Peningkatan Kinerja Perusahaan

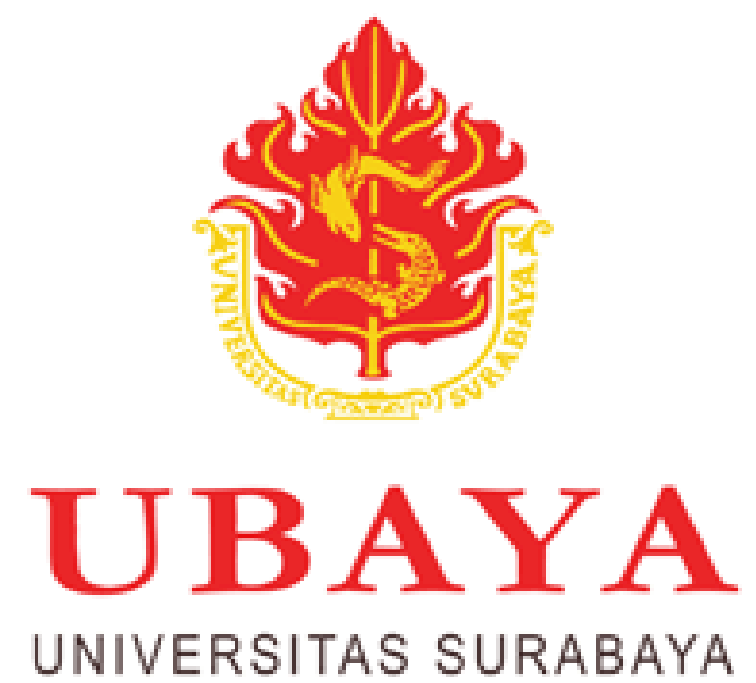

Bryan Julio Themy
130117124

Fakultas Bisnis dan Ekonomika

Universitas Surabaya

2019 


\begin{abstract}
ABSTRAK
Paper ini bertjuan untuk memahami bagaimana sebuah organisasi dapat dinilai berhasil dilihat dalam kinerja keuangan dan non-keuangannya , juga mengetahui Social return on investment atau yang biasa disebut rasio manfaat sosial dan suatu nilai invetasi merupakan salah satu variable untuk kinerja non keuangan.Salah satu keberhasilan sebuah organisasi yaitu kinerja bisa disebut juga sebagai gagasan untuk mencapai tujuan organisasi untuk mengambarkan arah perusahaan untuk menargetkan suatu perusahaan untuk mencapai tujuannya, dalam open innovation pendekatan yang tidak hanya melibatkan internal perusahaan, tetapi juga pihak ekternal dalam mengembangkan dan mengintegrasikan ide baru secara optimal untuk kepentingan perusahaan.,
\end{abstract}




\section{BAB I \\ PENDAHULUAN}

\section{Latar Belakang}

Artikel Jurnal bagaimana sebuah organisasi dapat dinilai berhasil dilihat dalam kinerja keuangan dan non-keuangannya. Pada kebanyakan saat ini, artikel junal tugas akhir yang dihasilkan masih berupa bentuk cetak (paper based) dan burning ke dalam organisasi / perusahaan banyak yang menggunakan indicator keberhasilan kinerja perusahaan tidak hanya dalam hitungan aset yang dimiliki melainkan dapat juga dari kinerja non keuangannya. Salah satu materi yaitu Pengembalian investasi sosial atau Social return on investment (SROI) yaitu suatu proses dengan cara mengukur nilai-nilai yang secara tradisional yang tidak tampak dalam laporan keuangan . Sosial, ekonomi dan lingkungan salah satu Faktornya . Dengan proses ini kita dapat mengidentifikasi seberapa efektif suatu perusahaan menggunakan modal dan sumber daya untuk menciptakan nilai untuk masyarakat luas ,Suatu peristiwa terjadi berdasarkan penilaian pribadi dan mencakup besarnya aspek pada suatu peristiwa pada penilaian pribadi dan didalam suatu kepercayaan disebabkan kurang atau tidak adanya informasi yang didapatkan berdasarkan keyakinan. Kinerja adalah kemampuan untuk mencapai suatu hasil dan efek untuk diperlukan dalam suatu lingkup yang bisa diukur, EO juga merupakan orientasi strategis tingkat perusahaan yang menangkap praktik pembuatan strategi organisasi, filosofi manajerial, dan perilaku perusahaan yang bersifat kewirausahaan. lingkungan kerja non fisik yang meliputi hubungan kerja sama antara atasan dan bawahan. Agar terciptanya lingkungan non fisik yang baik perusahaan perlu membuat sebuah kegiatan atau program bulanan yang mengumpulkan atasan dan karyawan sehingga dapat tercipta hubungan baik dalam perusahaan, baik untuk atasan dan karyawan maupun karyawankaryawan 


\section{BAB II \\ PEMBAHASAN}

\section{a. Firm Performance}

Menurut Pratono, Suyanto, Marciano, dan Zurbügg (2017) sebuah organisasi dapat dinilai berhasil dilihat dalam kinerja keuangan dan non-keuangannya. Social return on investment atau yang biasa disebut rasio manfaat sosial dan suatu nilai invetasi adalah salah variable untuk kinerja non keuangan. Dengan pendekatan subyektif dapat dilakukan penelitian kinerja dan mikro (Pratono, 2016) Pengembalian investasi sosial atau Social return on investment (SROI) yaitu suatu proses dengan cara mengukur nilai-nilai yang secara tradisional yang tidak tampak dalam laporan keuangan . Sosial, ekonomi dan lingkungan salah satu Faktornya . Dengan proses ini kita dapat mengidentifikasi seberapa efektif suatu perusahaan menggunakan modal dan sumber daya untuk menciptakan nilai untuk masyarakat luas ,Suatu peristiwa terjadi berdasarkan penilaian pribadi dan mencakup besarnya aspek pada suatu peristiwa pada penilaian pribadi dan didalam suatu kepercayaan disebabkan kurang atau tidak adanya informasi yang didapatkan berdasarkan keyakinan. Kinerja adalah kemampuan untuk mencapai suatu hasil dan efek untuk diperlukan dalam suatu lingkup yang bisa diukur. ada pemahaman yang berbeda untuk evaluasi kinerja pada tingkat ekonomi makro dan mikro. Kinerja ekonomi makro diukur melalui proses nilai tambah, yang menghasilkan nilai barang akhir yang dibuat dalam perekonomian. (Sujova, 2015)

Kinerja perusahaan dapat diartikan sebagai kemampuan mengukur kembali sumber data yang menghasilkan surplus.. (Drábek, Potkány 2008). Kinerja merupakan salah satu poin yang harus diperhitungkan ketika mengevaluasi kinerja internal ataupun external perusahaan,dapat juga untuk meningkatkan kinerja ke level tertinggi menjadi lebih banyak rintangan (Vosloban, 2012) Kinerja bisa disebut juga sebagai gagasan untuk mencapai tujuan organisasi untuk mengambarkan arah perusahaan untuk menargetkan suatu perusahaan untuk mencapai tujuannya (Elvin Bastiana, 2012)Organisasi yang mengambil risiko secara berani tidak selalu menimbulkan kinerja yang baik. Jika dilakukan akan adanya kemungkinan sesuatu yang egative yang tidak diinginkan, banyak risiko yang merugikan, namun setiap orang mempunyai cara dalam pengambilan risiko. Dalam pengambilan risiko ada yang berani dan ada pula yang bersifat pasif lebih memikirkan konsekuensi egative dari risiko tersebut . (Vemmy, 2012) Organisasi harus memilah dan memilih keuntungan dan kerugian suatu resiko yang akan diambil Open innovation menuntut jejaring bisnis yang mengandalkan kepercayaan (Pratono, 2018). Open innovation merupakan pendekatan yang tidak hanya melibatkan internal 
perusahaan, tetapi juga pihak ekternal dalam mengembangkan dan mengintegrasikan ide baru secara optimal untuk kepentingan perusahaan. Pendekatan ini lebih banyak diterapkan oleh perusahaan dalam berinovasi guna mengatasi dunia bisnis yang sangat kompetitif (Fadhilah, 2018) Open innovation diartikan juga sebagai pendekatan yang fleksibel, di mana dapat dikembangankan masuk kedalam pasar yang dapat mendukung kinerja perusahaan

\section{b. Entrepreneurial Orientation}

EO adalah orientasi strategis didefinisikan sebagai pandangan strategis (jangka panjang) yang di implementasikan oleh perusahaan untuk membentuk pola berkelanjutan yang berujung pada kinerja yang bernilai tinggi untuk stakeholdersbisnis. ( Aribawa, 2015)

Orientasi strategis perusahaan mencerminkan arah strategis yang dilaksanakan oleh perusahaan untuk menciptakan perilaku yang tepat dalam memperoleh kinerja yang terus unggul dalam bisnis. Maka ini membutuhkan suatu definisi secara umum yang dapat diterima oleh dunia bisnis yang nantinya akan menjadi awal dalam standarisasi definisi orientasi strategi, karena Beberapa pakar dalam ilmu manajemen mendefinisikan orientasi strategi dengan cara yang berbeda-beda. (Solikahan \& Mohammad, 2018) orientasi kewirausahaan sebagai entrepreneurial perusahaan yang berkaitan dengan inovasi produk, melakukan kegiatan yang beresiko dan yang pertama memperkenalkan inovasi yang proaktif serta dalam persaingan yang agresif maka diperlukan kegiatan yang intensif untuk mengungguli pesaing yang dicirikan dengan mengkombinasikan postur atau respon agresif untuk meningkatkan posisi dalam persaingan. orientasi kewirausahaan terbukti memiliki pengaruh positif dan signifikan terhadap kinerja perusahaan (Witjaksono, 2014) Orientasi kewirausahaan sebagai pendekatan baru dalam pembaruan kinerja perusahaan oleh perusahaan yang mulai mencoba bangkit dari keterpurukan ekonomi akibat krisis yang berkepanjangan, bentuk dari aplikasi atas sikap-sikap orientasi kewirausahaan dapat diindikasikan dengan indikasi kemampuan inovasi, proaktif, dan kemampuan mengambil risiko. ( Yasa, 2018) 


\section{c. Pengaruh Budaya Organisasi dalam Peningkatan Kinerja Perusahaan}

Sumber daya manusia mempunyai peranan penting baik secara perorangan ataupun kelompok dalam organisasi dan sumber daya manusia merupakan salah satu penggerak utama atas kelancaran jalannya kegiatan usaha, bahkan maju mundurnya perusahaan ditentukan oleh keberadaan sumber daya manusianya. Dan Setiap perusahaan selalu berusaha meningkatkan produktivitas karyawannya agar dapat bertahan, berkembang serta memiliki kepercayaan yang tinggi dari pihak luar perusahaan. Demi meningkatkan produktivitas karyawan, maka sering dilakukan pembenahan dan peningkatan sumber daya manusia dari karyawan. Didefinisikan oleh Schein (1985) dalam (Riani, 2011) budaya organisasi sebagai suatu pola dari asumsi-asumsi dasar yang ditemukan, diciptakan, atau dikembangan oleh suatu kelompok tertentu dengan maksud agar organisasi belajar mengatasi atau menanggulangi masalah-masalahnya yang timbul akibat adaptasi eksternal dan integrasi internal yang sudah berjalan dengan cukup baik, sehingga perlu diajarkan kepada anggota-anggota baru sebagai cara yang benar untuk memahami, memikirkan dan merasakan berkenaan dengan masalahmasalah tersebut. Budaya organisasi dibentuk sendiri oleh suatu kelompok organisasi untuk bergerak dalam mengatasi tantangangantantangan dimasa depan.

(Wardani, Mukzam, \& Mayowan, 2016) Hubungan Budaya Organisasi dengan Kinerja Karyawan Adanya hubungan antara budaya organisasi dengan kinerja karyawan atau anggota organisasi dapat tercermin dalam perilaku organisasi tersebut. Saat karyawan meniru perilaku yang sesusai dengan budaya organisasinya maka akan ada kepuasan tersendiri dan bahkan ada imbalan secara langsung atau tidak langsung. Budaya organisasi menjadi suatu pedoman perilaku bagi anggotanya yang secara tidak sadar diterapkan dalam menjalankan kegiatannya. 


\section{BAB III \\ PENUTUP}

\section{A. KESIMPULAN}

Sebuah organisasi dapat dinilai berhasil dilihat dalam kinerja keuangan dan nonkeuangannya dibuktikan dengan pengaruh budaya organisasi dalam Peningkatan Kinerja Perusahaan merupakan salah satu faktor pengaruh budaya organisasi dalam perusahaan yang mampu meningkatkan kinerja karyawan, oleh karena itu perlu adanya manajemen perusahaan yang baik dalam mengatur lingkungan kerja. hal ini diharapkan agar terciptanya hubungan yang baik antara pimpinan perusahaan dengan karyawan. Terbentuknya lingkungan kerja yang nyaman bagi karyawan menyebabkan meningkatnya kinerja karyawan yang kemudian sejalan dengan meningkatnya 


\section{Bibliography}

Aribawa, D. (2015). HUBUNGAN ANTARA ORIENTASI STRATEGIS DAN KEMAMPUAN INOVASI BERBASIS LAYANANSTUDI PADA UMKM KREATIF DI INDONESIA, 249-262.

Yasa, N. K. (2018). Peran Keuanggulan Bersaing dalam Memediasi Orientasi Pasar dan Orientasi, 1.

Akbar, Cahyo, Wibowo, \& Dkk. (n.d.). Pengaruh Efikasi Diri, Pengambilan Risiko dan Inovasi Terhadap Niat berwirausaha mahasiswa Univesitas Udayana, E-Jurnal Manajemen Unud, Vol 6, No. 10 5693-.

Business Economics and Management 2015 Conference, BEM2015. (2015). Influence of the Economic Crisis in 2008 on the Performance of Companies in Wood-processing Industry, 1.

Elvin Bastiana, M. M. (2012). Perceived Environment Uncertainty, Business Strategy, 787792.

Fadhilah. (2018). Paradigma Open Innovation dan Pengaturan Kekayaan Intelektual. Retrieved from https://actconsulting.co/paradigma-open-innovation-dan-pengaturankekayaan-intelektual/

FADILAH. (2018). Paradigma Open Innovation dan Pengaturan Kekayaan Intelektual.

Morikawa, M. (2016). 16 Examples Of Open Innovation- What Can We Learn From Them? Retrieved from https://www.viima.com/16-examples-of-open-innovation-what-canwe-learn-from-them

Pratono, A. H. (2016). Strategic orientation and information technological turbulence: Contingency perspective in SMEs. Business Process Management Journal, 22(2), 368-382.

Pratono, A. H. (2018). Does firm performance increase with risk-taking behavior under information technological turbulence? Empirical evidence from Indonesian SMEs. The Journal of Risk Finance, 19(4), 361-378.

Pratono, A. H., Suyanto, Marciano, D., \& Zurbügg, C. (2017). Social return on investment for community-based enterprise in Surabaya City. The Hong Kong Journal of Social Work, 51(01n02), 93-114.

Riani, A. L. (2011). Budaya Organisasi. Yogyakarta : Graha Ilmu.

Solikahan, E. Z., \& Mohammad, A. (2018). ORIENTASI STRATEGI DALAM PENGUKURAN, 191-197.

Sujova, A. (2015). Influence of the Economic Crisis in 2008 on the Performance of Companies in Wood-processing Industry, 2.

Vemmy. (2012). S.C. Faktor-Faktor Yang Mempengaruhi Intensi Berwirausaha, Jurnal Pendidikan Vokasi, 2 (1): 117-126.

Vosloban, R. I. (2012). The Influence of the Employee's Performance on the, 661.

Wardani, R. K., Mukzam, M. D., \& Mayowan, Y. (2016). PENGARUH BUDAYA ORGANISASI TERHADAP KINERJA KARYAWAN (Studi Pada Karyawan PT Karya Indah Buana Surabaya), 1.

Webera, B. (2014). Performance Reduction of PV Systems by Dust Deposition, 99-108.

Widhari. (2012). Jurnal Pendidikan Vokasi.

Witjaksono, H. P. (2014). ANALISIS ORIENTASI KEWIRAUSAHAAN DAN SUMBER DAYA INTERNAL PERUSAHAAN TERHADAP KINERJA MELALUI KEUNGGULAN BERSAING, 23. 